\title{
Crime and Society, a comparative criminology tour of the Republic of Macedonia
}

\author{
Natasha Georgieva Hadji Krsteski ${ }^{1}$, \\ ${ }^{I}$ (Faculty of security - Skopje/ University "St. Kliment Ohridski" - Bitola, Republic of Macedonia)
}

\begin{abstract}
The most common forms of organized crime in Macedonia are: drug trafficking, smuggling of migrants, cyber-crime, and in terms of financial crime is tax evasion and extortion. More vulnerable to the risk of organized crime are the police force units of border and traffic police, and police for crime combat. Crime in Macedonia by citizens classified in 7th place as a problem in the country. Macedonia in terms of organized crime ranks 98th place out of 148 countries in the Global Competitiveness Report of the World Economic Forum, with a value of 4.6, a total of 7 decimals. The legal framework, according to a report in the country in compliance with international standards, until now adopted all the necessary mechanisms and tools, and continually updated in line with GRECO. Drawback is the absence of a unified framework that statistical system tracking of crimes related to corruption and organized crime, which would include a higher, more efficient data exchange and cooperation between all institutions.
\end{abstract}

Keywords - organized crime, tax evasion and extortion, Macedonia, drug trafficking, cyber-crime, smuggling of migrants

\section{INTRODUCTION}

The analysis of survey data with representatives from the private sector shows that 12.5 percent of Macedonian companies recognize money laundering as relatively common. Fraud VAT is a phenomenon that exists for 27, 5 percent of companies, while 96.5 percent of the surveyed companies said that in the past year it was offered activities related to money laundering and VAT fraud.

The crime is considered for one of the key problems facing the country. The use corrupt methods by organized crime could significantly impair the stability of a country, especially if democracy is fragile and if long years of transition such as Macedonia. In the last decade, the Organized Crime Unit of the Ministry of Internal Affairs has registered 866 corruption cases, of which 466 were closed. According to the Interior Ministry, the number of detected offenses smuggling increased by $20 \%$, but the number of smuggled migrants is almost the same. The analysis of data obtained from a survey of private sector representatives, however, show that $12.5 \%$ of Macedonian companies recognize money laundering as relatively common, and $3 \%$ of the companies to be very common. Fraud with Value Added Tax (VAT) is very common for $2.25 \%$ of the companies relatively common for $12 \%$ of companies and very rare, but there is a phenomenon that $27.5 \%$ of companies. As factors that affect the suppression of such crimes may be said that is the independence and integrity of the institutions responsible for respecting the rule of law.

Drug trafficking - The pressure of Macedonia's borders and influence of major regional groups of drug trafficking will continue to shape the country's image as an attractive secondary route for the transit of illegal drugs. However, the GoM remains committed to the fight against illegal drugs and succeeded in implementing many elements of her four-year action plan, including placing a new focus on prevention. US Government through the training programs of the State Department for law enforcement conducted by the Ministry of Defence and DEA, will continue to work to strengthen the capacities of the Macedonian police, prosecutors and judges to effectively implement the national legislation against traffickers in narcotics.

Each year thousands of people are victims of human trafficking and migrant smuggling. Often they fall into the trap of criminals while passing the frontiers of the country. Striking amounts of money flowing into the pockets of traffickers and smugglers of migrants shows Macedonian state statistics. The Report of International organization for migration from November last year indicates such occurrences route for migrants from the Middle East via Turkey and the Western Balkans (Macedonia) to the European Union.

\section{ORGANIZED CRIME}

The most common forms of corruption used by organized crime to influence politicians in Macedonia are: bribery and trading in influence. Key reasons behind the corruption of politicians linked to organized crime: protection from prosecution, the impact on bureaucracy, receiving public contracts, personal (quick) profit, etc. Insufficiently strong legal framework regulating the financing of political parties, regulations on conflict of 
interest regulations for public procurement, etc., are shown as key reasons for the general corruption in the country. In Macedonia, as a developing country, there is a risk of high political corruption and "capture the state" in the hands of criminal networks because of the lack of controls on the profits generated by criminal activities, allowing them to exercise their influence on politics and the business sector. In the past five years it has made substantial changes in the legislation aimed at increasing the independence of the judiciary as one of the three separate and independent authorities, which often end the infiltration of organized crime groups. However, it added challenge of the role of the judiciary in anti-corruption policies and measures is the lack of transparency, i.e. the mechanism for feedback that will allow the public and civil society organizations to assess the integrity of the judiciary and its real efficiency and effectiveness the application of the general anticorruption policies and in dealing with corruption. Internal and external control over the work of judges are still one of the main challenges to overcome corruption and organized crime. EU report on Macedonia's progress in 2016 states that "judges in primary and appellate courts have submitted 2.419 requests for exclusion of cases with a potential conflict of interest, of which 1,818 were accepted." [1] There are claims for indirect political influence on the implementation and outcome of legal proceedings involving persons of high profile, particularly in relation to charges of organized crime and corruption as well as in cases involving politicians and media. The report emphasizes that the judiciary, particularly the prosecution must be independent, and that, as stated in Macedonia is more related to the human factor and potential than laws. Justice must be transparent and all data must be available. But in the current set-up, a key role have the Councils. Between states and by SELDI CSD system to monitor corruption, Macedonia is one of the states with the largest growth in the proportion of identifying judges as corrupt, according to the polls. This, coincides with the international assessment of political interference, inefficiency, favoritism of good financially secure individuals and corruption characterized the judicial system, and should be noted: 'The last case of wiretapping 2015 points is possible for political interference from high profile in the judiciary, which seriously undermines the independence of the judiciary'. The most common agents in the judicial corruption are advocates. The most common agents in judicial corruption, used by organized crime groups, are attorneys with experience in the judiciary, police, prosecutors, politicians etc. Several of the people interviewed for the project said they were aware of cases of corruption in the judiciary because of their knowledge acquired through work experience or through media reporting. Key factors for the development of corruption in the judiciary were presented in weak control system, low salaries, particularly among public prosecutors, close cooperation between judges and prosecutors and so on. Services of the fight against corruption and crime are naturally the primary goal of corrupt activities of organized crime. Departments or police officers who are more vulnerable to the risk of organized crime in comparison with others, border and traffic police, the police to combat crime and so on. Special measures to increase the integrity of the police officers are: integrity tests; education on ethics; systematic measures and others. The latest available statistics of the Basic Court Skopje 1 shows that in the last decade there were 41 charges against border police and customs charges against 17 customs report against lawyers and police officers. 35 percent of companies believe that corruption will always be present. Almost half $(49.5 \%)$ of Macedonian companies believe that corruption in the country can be significantly reduced, while $35.2 \%$ believe that corruption will always be present in the country, however, can be reduced [2]. The economy is mostly more optimistic about reducing corruption than citizens, which is also the case in Macedonia. At the same time, the economy is convinced that a significant number of public officials are involved in corruption. $47 \%$ of Macedonian companies believe that some public officials are involved in corruption, while $17 \%$ believe that the majority of public officials are involved in corruption, along with $4 \%$ who believe that everyone is involved, accounts for $68 \%$ of the representatives of the economy, who believe that public officials are in one way or another undertaking corrupt activities. Similar to other countries in the region, public services, which are subject to the highest risk of corruption are: inspections by the relevant authorities (labor, environmental, tax, health, etc.) (3.5\% of companies said they paid a bribe); obtaining permits and licenses $(2.50 \%)$, obtaining a building permit (2\%), obtaining bank loans (1.75\%), getting agreement on government procurement (1.25\%), payment of customs duties (1.25\%), see in Table 1 [3]. A comparison of the data shows that obtaining a credit agreement on public procurement includes similar level of corruption risk, suggesting that corrupt practices can be equally present in both the private and public sector. The greatest danger of corruption, however, is public procurement, where Macedonian companies have submitted requirements: a very short tender period for bidding, for example two weeks $(17.7 \%)$, tender with only one bidder $(11.7 \%)$ and tenders containing technical specifications that can fulfill only one company in the market $(9.75 \%)$, as in Table 2 . Money laundering and VAT fraud, according to the report, are highly represented in Macedonia, especially considering the experience of companies [4]. Namely, $96.5 \%$ and $92.5 \%$ of the companies in the past year was offered activities related to money laundering and VAT fraud, as in Table 2. The average value of a bargain in which there is money laundering is 120.000 denars or 1.947 euros [5]. Key industries that have identified the companies as a starting point of organized crime: the construction industry, waste management, tourism, insurance companies, industry production of tobacco, etc. especially construction and real estate risks for money laundering. 


\section{DRUG TRAFFICKING}

Macedonia is neither a major producer nor large regional transit point for drug trafficking. Government continues to progress in the suppression of drug trafficking and the implementation of its Action Plan for fight against drug trafficking, with particular attention in the coming years for prevention activities in schools among students and other vulnerable groups. Government of Macedonia (GRM) officially informed of an increase in illegal commercial sale and use of marijuana around the country, as well the number of seizures and criminal cases remained almost unchanged as in 2016. Macedonian law enforcement agencies continued to cooperate on issues covering drugs with regional partnerships with Serbia, Bulgaria and Turkey and with Western counterparts in Germany and Austria. The cooperation with Kosovo institutions for the operation of counter trafficking in illicit drugs is improved since early last year, with several institutions in both countries worked together throughout the year. Macedonian national strategy for combating drug trafficking sets out two general purposes: (1) to prevent new and reduce current drug use, dependence and damages/losses resulting from drugs to health and society; and (2) to take an active fight against drug production and cross-border drug trafficking, whereby would have prevented the crime rate and drug abuse [6]. The two main objectives are supplemented by the intersection of three domains of activity: coordination, international cooperation, monitoring and evaluation. GRM create an Action Plan in 2007 to implement this strategy and to align the Macedonian strategy/policy on the issue of drugs in the European Strategy, the European Action Plan and the UN Convention on drugs. This action plan was successfully implemented by creating a national body for coordination. Inter-ministerial commission is responsible for coordinating efforts to combat drug trafficking and the National Centre for Drugs and Drug Addiction - (National Center), which is responsible to provide objective, reliable and comparable information on the issues of drugs and drug addicts, according to the EU standards. In 2008, GRM create ongoing Action Plan for implementation of the National Strategy on Drugs that included the signing of agreements, protocols and memoranda of cooperation with the EU and neighboring countries to suppress the illicit drug trafficking and criminal activities related to drugs. According to the 2016 report published by the National Center, the implementation of the Action Plan has been 100\% realized [7]. Macedonia is a signatory to the Convention on drugs UN 1988godina, single Convention which was amended by the 1972 Protocol, and the 1961 Convention on Psychotropic Substances. Macedonia is a signatory to the UN Convention against Corruption and Transnational Organized Crime and its three protocols. In 2010, Macedonia has signed several bilateral agreements: one for police cooperation with Kosovo; another for cooperation in the field of law enforcement in the Czech Republic; and the third with the Republic of Serbia on regional issues of trade. Macedonia also signed this year, Memoranda of Understanding in the field of cooperation in law enforcement with Albania, Bosnia and Herzegovina, Serbia and Montenegro. Synthetic drugs on the Macedonian market is smuggling from Bulgaria and Serbia, but also from the Netherlands. There are no reports on local illicit manufacture or processing of heroin or illegal synthetic drugs. Only one pharmaceutical company in the country is legally authorized to produce opium and processed for the purposes of medicine. The allowable production and use of opium for pharmaceutical raw materials, some 160 hectares in 2010, takes place under the supervision of the Ministry of Health which shares data on a regular basis with the International Board for Narcotics Control in Vienna. According to government sources, illegal cultivation of marijuana for commercial purposes has increased in the area of North-West Macedonia and throughout other parts of the country and takes place in greenhouses and fields. This marijuana is offered for sale to domestic and foreign markets. According to statistics of the Ministry in 2016, 'criminal charges related to drugs were brought against 649 persons, which means an increased number of 340 persons compared to 2015 for a total of 500 criminal cases. From criminally responsible persons, 566 persons were charged with illegal production and trafficking of narcotics and psychotropic substances. Stand out 68 cases of enabling the use, i.e. drug trafficking committed by 83 people. These cases have resulted in seizures of 440 kilograms of marijuana, 37 kilograms of heroin, $2.6 \mathrm{~kg}$ of cocaine, one kilogram of liquid cocaine, cannabis plantations 4.108, 11,152 tablets of amphetamine and 791 grams methamphet-amines', as in Table 3 [8]. Sources from the Ministry of Interior (MoI) reported that the decline in seizures of heroin is a regional trend is the result of disease of the opium poppy that significantly influence the production of poppy. The price of heroin on the market did not fall, but diluted form, i.e. mixture between inert substances and active ingredient of street heroin - increased. Cooperation and communication of MoI with partners in neighboring countries and Western Europe remains strong. The cooperation with Kosovo as a neighboring country continues is improved. Macedonian findings contributed to the seizure of 74 kilograms of heroin in Greece, the event coordinated by the US Agency for fight against illegal drug trafficking (DEA). Macedonia also contributed to the seizure of eight kilograms of cocaine in Sweden and two kilograms of cocaine in Germany, resulting in several arrests. Initiatives led by Macedonia yielded the seizure of 5 kilograms of cocaine in Austria and an arrestment of four people. Macedonian cooperation with the agencies of law enforcement and interdiction of illegal drug trafficking in Bulgaria, Germany and Austria resulted in the arrest of 33 people as part of a dealer network of drug based in Macedonia who was selling ingested heroin on the 
streets of Frankfurt and Vienna. The arrests include the main organizers of the network six-member family from Veles. In cooperation with the services of the neighboring countries, managed to seize 600 grams of cocaine and arrested two people, one of which was a refugee who had been sought for the murder of two children in an internet cafe in Skopje. Macedonian Customs continue to strengthen its intelligence units and mobile teams. Police officers described the cooperation with their counterparts from the customs service as a constantly active and improved over the past few years. The opening of the National Center has improved the quality and reliability in statistics regarding drug abuse and addiction. Staff at the Ministry of Health estimated that 9,000 registered drug users in the country. The most commonly used drug is cannabis, followed by heroin. Treatment and rehabilitation are carried out in 12 state hospital clinics for drug users. These clinics are registered to monitor the course of methadone treatment for heroin addicts. 10 of these 12 clinics of the University Clinical Centre in Skopje, and two are located in Macedonia's two main prisons (the largest is with over 60\% of the total population of prisoners in the country). Funding for clinics and drug treatment comes from the national budget. According to a survey conducted in 2016 by the National Center (including the inside of prisons), '75\% of patients said they were satisfied with the overall conditions of treatment and $63 \%$ said that due to the success of the treatment they are able to work' [9]. 1,500 prisoners in the main prison in the country, estimated as quarter of prisoners were identified as a drug users, mostly heroin addicts. Staff at the Ministry of Health confirmed that rehabilitation centers are overflowing. Hospital treatment in specialized institutions consisted of detoxification is followed by medical/vitamin therapy also limited family therapy, counseling and social work. Staff for monitoring the development subsequently of detoxification, or programs for reintegration into society of treated drug addicts were inadequate. There are only three centers for social reintegration and rehabilitation in Macedonia. Macedonian Ministry of Education, NGOs and international support, has successfully implemented three pilot prevention programs in three different cities in Macedonia, each involving training of teachers as well as training programs for trainers. Educational materials on prevention in the form of leaflets and posters were also distributed in the pilot schools. National Center evaluated the success of these programs as high - among students especially in terms of preventing the use of cannabis and alcohol, but noted that there was little or no attention in terms of controlled substances such as benzodiazepines and other tranquilizers which, according to the European drugs project implemented in schools, are the most problematic issues between the school population in Macedonia. The center also had a critical view of the effect of the project, because only draws one percent of the total number of students in Macedonia. In response, the GOM created the National Program for Prevention of providing information useful for students and other sensitive contexts, such as young people living on the street and those in prison - to avoid drug use. In 2016, GRM also provide new opportunities for treatment trials using the drug buprenorphine. Three private psychiatric clinics to treat patients opened in 2016 and has treated 132 patients. In Strumica a town known for being a significant problem with drug use, the local NGO to combat the use of drugs supported by the municipal authorities and the Macedonian Orthodox Church has joined efforts and opened a private clinic for rehabilitation of drug addicts. Local businesses have provided funds to renovate the building society which would be used as a center for treatment. Centre meant a great success for the community, homogenizing collaboration between local government and the people and providing a place for free rehabilitation outside the state system. In June 2016, the Bureau of Public Security in the Ministry of Interior in cooperation with international partners conference in Macedonia for the analysis of organized forms of drug crime and capacity to suppress illegal drug trafficking, has gathered experts to combat drug use. Seventy experts from Macedonia and international experts from the European Commission, SECI Centre, Interpol and DEA Agency were present and participated.

\section{MACEDONIA RECORDED GROWTH OF CYBERCRIME}

Most common cases of cyber-crime are damaging and unauthorized access to a computer system, processing and use of fake credit card, misuse of personal data, damage to software piracy and making unauthorized financial transactions by computer. Therefore apart from banks and some major financial institutions in Macedonia, here and there invest in protection of consumer's personal data, and invest in such solutions other companies such as online stores to, which are not even so much protected and are the target of such attacks, and because of that will follow a growth of the cyber-crime in Macedonia. The companies in Macedonia have no interest to protect themselves from this type of crime. The reasons for it sees the lack of funding and lack of information on information security. The first reason was financial, means investing in such security solutions or products is very expensive. It can cost up to 10 thousand dollars for a project, depending on the client. But in Macedonia usually works as an administrator, works as a man in charge of security and administrator for databases and any position to complete just one person or two to complete 10 things and because there are such problems, especially in Macedonia. In this country there are people that offer hacking services for a price. There are those people who enthusiastically want to learn and try to know what is legal, what is not, raised problems, entered into a computer, changed the website, or deface or stolen credit cards, as illegal activity. Laws exist, but there is lacks of awareness at the executors for better protection. Characteristic 
for the Internet criminals is that it is a matter for the young population. One of the specific cases is the discovery of a group of hackers who entered into the systems of banks and certain accounts funds. According to the records of the Ministry in 2016 were discovered two criminal groups that were engaged in cyber-crime. One bought products using counterfeit payment cards, while the other set of ATM, which received data on payment cards and committed 500 illegal financial transactions. The statistics show a significant rise of cybercrime in Macedonia. 'In 2016 are registered 61 case of cybercrime, in 2015 committed 48 offenses, and in 2014 noted a threefold increase compared to previous years. According to the Ministry of Interior in 2013 recorded 10 crimes committed with a computer, which is double the previous year, as in Table 4. In 2012, the Macedonian Ministry of Interior was part of an international police operation coordinated by the US FBI in suppressing the group cyber criminals from several countries, operation called CARDSHOP' [10]. The unit of computer crime of the department of financial crime at the center of suppressing organized and serious crime in the Ministry of Interior of the Republic of Macedonia, as part of this operation detained two persons, citizens of the country for which there were doubts that were part of the criminal scheme, i.e. certain Internet pages together with other people offering unauthorized sales data from credit cards and bank accounts owned by foreign nationals. That same year among the registered cases of cyber-crime, two that drew more attention were the major police action in which were arrested more than 10 people, and determined cyber-crime during the bidding for the procurement of 150 police vehicles. Participants of electronic auction had difficulties and difficult access in the use of electronic procurement system due to unauthorized traffic system. Because of this, the Unit for Cybercrime of the Interior Ministry to the Public Prosecution Skopje submitted a special report on the crime of "damage and unauthorized entry into a computer system" (Article 251 of the Criminal Code of the Republic of Macedonia) [11]. Therefore the sanctioning of these crimes is regulated by Article 251 of the Criminal Code (a computer system) Official Gazette No.37 / 1996, tabled in the Criminal Code in 1996 and since then this Article is applied in practice. Falls in Chapter 23, Crimes against property of the CC of Macedonia. Paragraph 1 of this article says, he who unlawfully enter, change, announce, hide, delete or destroy computer data or programs, or otherwise enters into a computer system with the intention either to obtain an anti-dust material gain or damage another shall be punished by a fine or imprisonment up to three years. Cases of cyber-crime: computer fraud, theft and financial fraud by computer, falsification of data in electronic form, computer vandalism and computer viruses.

In 2016 the commission of these crimes caused damages to the state amounting to about 22 million denars. Computer crime is extremely serious type of crime with serious consequences. This crime usually performed in a wider area. Of the approximately 100 people who are covered by the prosecution in Macedonia in 2016, a third persons are not citizens of Macedonia. Mostly it comes to unauthorized entry into a computer system, computer fraud, and using of a false credit card, and computer forgery. With the growing power of cyber-crime faced by the countries of the region, is required greater training of judges and prosecutors and enforcement of legal regulations, continuously since 2008 at the Academy for Training of Judges and Prosecutors where has being hold educational seminars, meetings and workshops was. So far are trained 167 judges and public prosecutors, court counselors, people who are directly involved in the prevention, detection and prevention of cybercrime, which, is part of organized crime. Prosecutors and judges must have a basic knowledge of this type of crime, which must constantly promote. Judges must be ready to fight. Countries in the region are now facing a shortage of training materials but also a lack of trainers. It is required joint action of all countries in the region, but in Macedonia is necesery international experience and international trainers.

Successful handling sophisticated forms of cyber-crime can be realized by taking measures both at national and international level, because the efficiency is higher and often only possible if cybercrime is treated on international level. Only with such an approach to the problem we will be able to achieve success in the fight and eradication of this type of crime, and therefore the best way to promote and modern society based on the rule of law. Gathering the participation of experts from the institutions responsible for the suppression of cybercrime from Southeast Europe and Turkey, has the goal to establish effective cooperation mechanisms at national and regional level, exchange of information, strengthening and harmonization of research capacity, subtraction and confiscation of property acquired through computer crime and preventing money laundering through Internet. Macedonia strongly supports the private sector and shares the opinion of the exceptional importance of his involvement in the identification process to investigate computer crime and money laundering. Support from the private sector through cooperation and timely exchange of information can directly affect the performance of the agencies of law enforcement. The borders are not a problem for criminals, and a problem for institutions prosecute. The Convention on Cybercrime that has already been endorsed by 40 countries worldwide, is a tool for successfully dealing with this, but with all types of conventional crime. Now it is easier to freeze assets acquired through computer crime, while by working to provide the evidence necessary for initiating a criminal case, and the need for rapid and effective action by all stakeholders from the fact that the evidence suggests this type crime can quickly disappear. The global dimension holds cybercrime at a time when the Internet and computers are commonplace, and affect all aspects of modern society, the citizens, democratic 
institutions, until the media. Noting that almost no crime today launched with the use of electronic devices such as computers, tablets, mobile phones. Most computer crime is never reported or recorded by law enforcement authorities, and only one percentage of reported cases is in the court. The volume of cases of fraud via the Internet, is measured in billions of euros, money that in this moment are taking place at this or that sort of criminal, pointing to the need to include every individual in reporting the various attempts at fraud, which would then result with appropriate and timely response of law enforcement. Identified are realistic goals and tangible results to be achieved, also are planned specific activities through which the Republic of Macedonia and the region will confirm its capacity to deal with cybercrime. It is a wide range of crimes: damage and unauthorized intrusion into computer system, processing and use of false payment card, misuse of personal data, damage to software piracy, and all other illegal forms resulting from computer technology. Criminals are usually young people, so the growing trend of Internet crime is not a surprise. The greater is the use of the Internet in every sense, as people are more present on the Internet, as more business moves online, so criminals are caught by that wave and they move the cyber world. Macedonia is no exception to global trends. Most attractive are bank accounts. One of the specific cases is the discovery of a group of hackers who entered into the systems of banks and taken funds from certain accounts. 'More than 100 thousand customers took away small amounts but managed to bring to their own accounts in a neighboring state a million euros' [12]. Since cyberspace has no boundaries, crimes cannot elucidate without international cooperation. Often perpetrators can operate from another country. Prosecuted are several hundred people and one third of them are citizens of Macedonia. The laws in Macedonia in this area are good and in line with European regulations. There is lack of awareness of the existence of this type of crime. People need to understand that any use of the Internet should be safe. Just as when opening a store to take protective measures, it needs to react and when it comes to cyberspace. For each use of the Internet should be provided appropriate protocol for protection. Grow the number of Facebook offenses so the awareness of Macedonian citizens for abuse of cyberspace grows, shows statistics at the Agency for protection of personal data. 'Therefore in 2016 are received more than 180 complaints. Most of them, 107 are related to the creation of fake profiles on somebody else's name on Facebook, 40 refer to hacking Facebook profiles, 20 relate to various types of abuse committed on social networks' [13].

\section{SMUGGLING MIGRANTS}

Government of Macedonia promoted the National Strategy and National Action Plan on struggle against human trafficking and illegal migration 2013-2016. Strategy and Action Plan is a comprehensive policy to combat trafficking by coordinated action by all relevant institutions and organizations in which the protection of human rights of victims is maxim. The key innovative features of the Strategy and National Action Plan foresee strong preventive measures to act on the reasons that the roots of human trafficking and working with vulnerable groups in order to prevent this phenomenon. It is done to raise awareness among the general population, especially among youth, economic empowerment of vulnerable groups by facilitating access to the labor market and organizing campaigns to reduce the demand for services from victims of trafficking. Ministry of Labor and Social Policy has established a referral mechanism for assistance and protection to victims of trafficking in the future devoted to work to strengthen this mechanism in accordance with international conventions and standards. As vulnerable groups or potential victims of trafficking that should be given special attention in the coming period are children and young people with little or no education aged 10 to 22 years from poor and dysfunctional families, and children without parental care. During the year are identified eight victims of trafficking, including four minors and four adults, of these six females and two males. Four people were Macedonian nationals, three were from Albania and one from Bosnia and Herzegovina. Past years, the Ministry of Interior, make amending the Criminal Code by introducing stiffer penalties for perpetrators of the criminal act of human trafficking, especially when it comes to minors, introduce standard operating procedures for dealing with victims which are identical with ten countries of SEE, introducing data base of offenders and victims of trafficking, conducting training for 600 police officers, establishing a public shelter for victims of trafficking [14]. The recent Action Plan for 2013-2016 brought a number of new activities that will be able further to reduce human trafficking in the country. In realization of this four-year plan the government contributes with 9.3 million denars. Until a few years legal penalties for trafficking were three years, but the case law, indicated that rarely impose prison sentences and were not treated crimes when the victim is a child. The amendments to the Criminal Code and the penalty is four years and for minor or when the victims are children punishment is eight years in prison. Such penalties and more imposing send a clear message that unacceptable nowadays to exist still slavery, which nowadays is human trafficking. The National Strategy and National Action Plan to Combat Human Trafficking and Illegal Migration 2013-2016, forms local committees on human trafficking in cooperation with units of local government and establish mobile teams at the local level to identify, support and assist to potential victims and groups at risk [15]. The National strategy to combat human trafficking and illegal migration is a document that provides for measures and activities of the institutions aimed at detecting and prosecuting perpetrators, as well as a comprehensive approach to improving 
the status of victims of human trafficking and illegal migration in the country. National Strategy and Action Plan to Combat Human Trafficking and Illegal Migration 2013-2016 is the third strategic document prepared by the National Commission on the needs of the field and reflects current trends in the Republic of Macedonia. The activity of the commission is preparation of documents stems from the commitment of the Government of the Republic of Macedonia in providing an effective response to human trafficking and illegal migration. These two documents are a national response to the international obligations of the Republic of Macedonia and effort to unite all the attitudes, activities and resources into a coherent framework and a unique approach to sustainable development in the promotion of human rights of victims of trafficking. Partnership approach of the National Commission with relevant institutions, associations and international organizations is important in the creation of the contents of the NAP 2013-2016. In the production are taken into account recommendations from the US State Department in the ranking of Macedonia in Tier 1 countries in 2011, the EU Strategy to combat trafficking for 2013-2016, the recommendations of the evaluation of the NAP 2009-2012, and other relevant documents [16]. Nationwide in 2001, it was established a National Commission to Combat Human Trafficking and Illegal Migration (CC) with the task of coordinating the work of all institutions involved in the prevention, protection and investigation of human trafficking. At the head of this committee is national coordinator. Under the Penal Code in 2003 is established Secretariat - a body responsible for accepting and implementing the decisions of the National Commission, which includes representatives of international organizations, NGOs, embassies and government bodies. Part of the Penal Code is a subset of children - victims of trafficking, established in 2003 in order to adapt the work of the committee to the needs of this sensitive category of victims, and to put special emphasis on the prevention of child trafficking and improving protection of juvenile victims. Furthermore, in 2009 it was established a new body, the National Rapporteur, whose primary role is to oversee the overall activities for combat trafficking. This body as envisaged in the National Action Plan is responsible for collecting and analyzing data (qualitative and quantitative information) for broad topics related to human trafficking in the context of prevention, protection and prosecution. Also, one of the roles of this feature is tracking and monitoring the implementation of standard operating procedures. National Referral Mechanism (NRM) operates within the Department for Equal Opportunities of the Ministry of Labor and Social Policy (MLSP) of 2005 in order to provide identification, assistance and protection to victims of trafficking, whether a child or an adult. The primary goal of this office is to coordinate the work of 58 professionals (social workers) from 27 centers for social work (CSW) around the country and to cooperate with all agencies involved in the protection of victims addition is part of the Transnational Referral Mechanism (TRMU) which connects the entire process of referral from initial identification to return and help the countries of transit and countries of destination and countries of origin, including cooperation between the various government departments and NGOs. The strategy sets out the strategic priorities for combating human trafficking, defines the tasks of the responsible institutions, harmonize inter-institutional actions at local and regional level, provides improved quality of services for victims, intensify investigation, prosecution and conviction of perpetrators. The Action Plan aims to plan coordinated activities of all stakeholders and actors but also to provide a broad political and financial support for implementation of the activities under the plan. In addition to this document has been prepared and an action plan to combat trafficking in children. The document is clear and establishes clear goals with realistic time frames. In the first months of 2008, the Government adopted the standard operating procedures for dealing with victims of human trafficking (SOPs) which aim to provide support and protection to all victims of trafficking through a comprehensive step by step approach which is based on human rights. SOP also predict an institutional framework for cooperation that will focus on the victims of trafficking in human beings (THB). SOP involves taking specific measures in the following areas: identification and referral, immediate care and assistance, reintegration of criminal procedure. Identification documents and protection of victims of trafficking are [17]:

- Indicators for the identification of victims of trafficking,

- Program of support in the reintegration of victims of trafficking,

- Program of support in the reintegration of child victims of trafficking, and

- Standard operating procedures for dealing with victims of human trafficking.

I. FIGURES AND TABLES

Table 1. Public services, which are subject to the highest risk of corruption Public services Results (\% of 


\begin{tabular}{|l|c|}
\hline \multicolumn{1}{|c|}{} & $\begin{array}{c}\text { companies that } \\
\text { said they paid a } \\
\text { bribe) }\end{array}$ \\
\hline $\begin{array}{l}\text { Inspections by the relevant authorities (labor, } \\
\text { environmental, tax, health, etc.) }\end{array}$ & 3.5 \\
\hline Obtaining permits and licenses & 2.50 \\
\hline Obtaining a building permit & 2 \\
\hline Obtaining bank loans & 1.75 \\
\hline Getting agreement on government procurement & 1.25 \\
\hline Payment of customs duties & 1.25 \\
\hline
\end{tabular}

Source: [3]

Table 2. Corruption in public procurement, money laundering and VAT fraud

\begin{tabular}{|l|c|}
\hline \multicolumn{1}{|c|}{ Subject of corruption } & $\begin{array}{c}\text { Results (\% of } \\
\text { companies that } \\
\text { said they paid a } \\
\text { bribe) }\end{array}$ \\
\hline Very short tender period for bidding, for two weeks & 17.7 \\
\hline Tender with only one bidder & 11.7 \\
\hline $\begin{array}{l}\text { Tenders containing technical specifications that can } \\
\text { fulfill only one company in the market }\end{array}$ & 9.75 \\
\hline Money laundering & 96.5 \\
\hline VAT fraud & 92.5 \\
\hline
\end{tabular}

Source: [4]

Table 3. Types of drug in drug trafficking

\begin{tabular}{|l|c|}
\hline \multicolumn{1}{|c|}{ Type of drug } & $\begin{array}{c}\text { Results } \\
\text { (trafficing in } \\
\text { kg., tablets and } \\
\text { gr.) }\end{array}$ \\
\hline Marijuana & 440 \\
\hline Heroin & 37 \\
\hline Cocaine & 2.6 \\
\hline liquid cocaine & 1 \\
\hline cannabis plantations & 4.108 \\
\hline Amphetamine & 11,152 tablets \\
\hline methamphet-amines & 791 grams \\
\hline
\end{tabular}

Source: [8]

Table 4. Registered cases of cybercrime

\begin{tabular}{|c|c|}
\hline Year & $\begin{array}{c}\text { Results } \\
\text { (offenses) }\end{array}$ \\
\hline 2016 & 61 \\
\hline 2015 & 48 \\
\hline 2014 & 30 \\
\hline 2013 & 10 \\
\hline 2012 & 5 \\
\hline \multicolumn{2}{|c|}{ Source: $[10]$} \\
\hline
\end{tabular}

VI. CONCLUSION

The indicated advantage of the paper is the fact that is prepared over the basis of the large database of the Ministry of Interior and the State Statistical Office of Macedonia. This fact means that the paper depicts the case empirically precise, and make an opportunity to be comparable with similar papers, also to be evaluated its subject of research. The limitations are that the data used in the paper is secondary and not primary, so it may be biased and to exist certain percent of variation in the results. Possible applications of the paper are in the large academic researches for writing a book, for writing expertly reports, doctoral dissertations and etc.

The main points of the paper, are: organized crime, drug trafficking, cyber-crime and smuggling migrants. In the first topic, main point is given to the corruption in the public and private sector, and its 
modalities. In the second topics main role is given to the various types of drugs that are trafficked, and certain important information about this topic. In the third topic general role is given to the cyber-crime, and its trend during the past five years, and its modalities. In the last topic is given attention to the smuggling of migrants and its structure, also the law regulation of it.

\section{ACKNOWLEDGEMENTS}

I would like to express my special thanks of gratitude to the Ministry of Interiors of Republic of Macedonia as well as to the State Statistic Office of Republic of Macedonia who gave me the golden opportunity to its data base necessary to do this wonderful paper on the topic (Crime and Society, a comparative criminology tour of the Republic of Macedonia) and also helped me in doing my own research in which I learnt so many new things. I am really thankful to them. Secondly I would also like to thank to all academic stuff who helped me a lot in finalizing this paper within the limited time frame with their unique literature.

\section{Journal Papers:}

\section{REFERENCES}

[1] Angeleski, M., Stojanovski, D., Nedelkovska, M., Kurtevska, I., Gaberova, N., Miloseski, D., The financial crime in Republic of Macedonia, European Scientific Institute, European Scientific Journal, special edition vol. 1, 2014, 12-16,

[2] Nikolovski, B., Kokolanski, V., Achkoski, J., Dojcinovski, M., Breach of Personal Security through Applicative use of Online Social Networks, TEM Journal, 2 (4), 2014, 15-19,

[3] Ackoski, J., Dojcinovski, M., Cyber terrorism and cyber-crime - threats for cyber security, First Annual International Scientific Conference, 09 June, Makedonski Brod, 2012, 17-22.

Books:

[4] Kambovski, V., Organized Crime (August 2, Stip, 2005), 45-57, 185,

[5] Lyman, M., Poter, G., Organised Crime (Magor, 2009), 56-69,

[6] Labovic, M., Nikolovski, M., Organized Crime and Corruption (Faculty of Security Skopje, 2010), 5-9,

[7] Achkoski, J., Dojchinovski, M., Security of computer systems, computer crime and computer terrorism, Military Academy, Skopje, 2011, authorized the script, 16-20.

Theses:

[8] Georgieva Hadji Krsteski, N., Criminological - law enforcement aspects of the abuse of power and authority in the country, doctoral diss., University 'St. Kliment Ohridski' - Bitola, Faculty of security Skopje, 2015, 142-159.

\section{Proceedings Papers:}

[9] Tudzharovska- Gjorgievska E. 2015. Follow the link between corruption and organized crime: document for policy-Part. MCIC, Skopje 2015, 52-68

[10] Ministry of Interior, Report on Organized Crime and Corruption, Ministry publish, Skopje, 2016, 14-23,

[11] Ministry of Internal Affairs, Statistics Specific cases relating to organized and economic crime, State publish, Skopje, 13-25

[12] Kalajdziev D.. Court efficiency in dealing with organized crime and corruption - report 'monitoring of cases of organized crime and corruption' in Macedonia, Skopje: Coalition of Civil Associations All for Fair Trials, Skopje, 2013, 62-78

[13] State Commission for Prevention of Corruption, National Programme for Prevention and Repression of Corruption, State program for the prevention and reduction of conflict of interest for the period 2011 2015, State publish, Skopje, 2016, 24-35

[14] State Strategy for Combating Money Laundering and Terrorism Financing, Financial Intelligence, State publish, Skopje, 33-49

[15] Ministry of Interior of the Republic of Macedonia, Annual Report of the National Rapporteur on combating human trafficking and illegal migration in the Republic of Macedonia, Skopje, 2016, 24-35,

[16] Government of the Republic of Macedonia, Strategy for Combating Human Trafficking and Illegal Migration in the Republic of Macedonia, Skopje, 2006, 54-68,

[17] Government of Macedonia, National Action Plan to Combat Human Trafficking and Illegal Migration in the Republic of Macedonia, Skopje, 2006, 22-35,

[18] Government of the Republic of Macedonia, Action plan to combat child trafficking in the Republic of Macedonia, Skopje, 2006,41-59. 